\title{
Study and Modelling of Energy Supply at Moti Island-Ternate Based on Renewable Energy
}

\author{
Bahrud Kahar $^{1}$ and Ridho Hantoro ${ }^{1}$
}

\begin{abstract}
Until now in North Moluccas province especially in the district of Ternate city due to geographical conditions, electrification for the islands outside of Ternate be uneven and cannot meet the overall demand for electricity. As well as Moti Island is one of the sub-districts of Ternate city, the operation of diesel generators was limited at night which hours 18:30 to 23:00 or 4.5 hours/day. The main problem is the high operating cost of diesel generator, especially of the fuel cost, availability and the high cost of spare parts. This study proposes a configuration models of hybrid power generation system on the Moti island between diesel generators and renewable energy as a solution to meet the electricity needs for 24 hours, because the Moti island has a energy of annual average solar radiation is $5.96 \mathrm{kWh} / \mathrm{m} 2 /$ day and annual average wind speed of $3.8 \mathrm{~m} / \mathrm{s}$. Calculation and optimized for the potential of renewable energy and configurations models of hybrid power generation system using software HOMER (Hybrid Optimization Model for Electric Renewable). The simulation results provide a configuration models of the optimal hybrid power plant is the first option: PV (50\%) + Diesel (50\%) configuration with the NPC lowest value is US\$ 1,531,546 and more efficient fuel consumption per year is $47.1 \%$ of the fuel consumption on the moti island for this time, And the second option is an alternative configuration: PV (70\%) + Diesel $(30 \%)$ configuration with a NPC value is US \$1,577,512 and also more has efficient fuel consumption per year $64.3 \%$.
\end{abstract}

Keywords — potential energy, hybrid power generation, moti island.

\begin{abstract}
Abstrak-Sampai saat ini di provinsi Maluku Utara khususnya dalam wilayah Kota Ternate karena kondisi geografis, elektrifikasi bagi pulau-pulau di luar Pulau Ternate menjadi tidak merata dan belum dapat memenuhi kebutuhan listrik secara keseluruhan. Seperti halnya Pulau Moti sebagai salah satu kecamatan di Kota Ternate, pengoperasian generator dieselnya terbatas pada malam hari yaitu jam 18:30 - 23:00 WIT atau 4,5 jam/hari. Selain tingginya biaya operasional generator diesel terutama biaya bahan bakarnya juga faktor ketersediaan dan mahalnya suku cadang menjadi persoalan utama dari pengoperasian generator diesel tersebut. Studi ini mengusulkan model konfigurasi Pembangkit Listrik Hibrida (PLH) di Pulau Moti antara generator diesel dan energi terbarukan sebagai solusi untuk memenuhi kebutuhan energi listrik 24 jam, karena Pulau Moti memiliki potensi energi radiasi matahari rata-rata per tahun sebesar 5,96 kWh/m2/hari dan kecepatan angin rata-rata per tahun sebesar $3,8 \mathrm{~m} / \mathrm{s}$. Perhitungan potensi energi terbarukan yang potensial dan model konfigurasi pembangkit listrik hibrida yang optimal menggunakan software HOMER (Hybrid Optimization Model for Electric Renewable). Hasil simulasi memberikan model konfigurasi pembangkit listrik hibrida yang optimal pilihan pertama yaitu: konfigurasi PV(50\%) + Diesel(50\%) dengan nilai NPC terendah sebesar US\$ 1.531 .546 dan pemakaian bahan bakar per tahun lebih irit 47,1\% dari pemakaian bahan bakar saat ini di Pulau Moti, dan konfigurasi alternatif pilihan kedua yaitu: konfigurasi PV(70\%) + Diesel(30\%) dengan nilai NPC sebesar US\$ 1.577 .512 dan juga pemakaian bahan bakar per tahunnya lebih irit $64,3 \%$.
\end{abstract}

Kata Kunci_potensi energi, pembangkit listrik hibrida, pulau moti.

\section{INTRODUCTION}

$\mathrm{T}$ ernate city is one of the districts in North Moluccas province, it has five inhabited islands and three other small uninhabited [1]. This geographical conditions led to the spread of electrification for islands inhabited outside the island of Ternate becomes uneven and forced the government to supply diesel generator to the islands for their electricity needs. As well as Moti Island is one of the subdistricts in Ternate city (Fig 1), operation of the diesel generators was limited at night which hours 18:30 to $23: 00$ or 4.5 hours/day. Diesel generator operation of this limited because of high fuel cost. Increase in the fuel price has an impact on the high operational costs. Besides the maintenance cost of diesel generators very large because availability and the high spare parts cost so that must be in a message to distributors outside the district. That solutions for reducing consumption and dependence on fossil fuels for

${ }^{1}$ Bahrud Kahar and Ridho Hantoro is with Departement of Physics Engineering, Faculty of Industrial Technology, Institut Teknologi Sepuluh Nopember, Surabaya, 60111, Indonesia. E-mail: bahrudkahar@gmail.com; hantoro@ep.its.ac.id. diesel generator is by owned exploiting renewable energy potential [2].

Moti island rich in sunshine with an average annual radiation of $5.96 \mathrm{kWh} / \mathrm{m} 2 /$ day [3] and also have an average per year wind speed of $3.8 \mathrm{~m} / \mathrm{s}$ [4]. The potential renewable energy need to be analyzed so that it can be a source of alternative energy for reduce that need fuel oil and switch on the use of renewable energy.

This study was conducted in Moti Island Ternate (Fig 1) by proposing a configuration modeling Hybrid Power generation consisting of diesel generator configuration, renewable energy configuration and combined configuration of diesel generators and renewable energy with a 24 hours operation pattern. Analysis data using software HOMER (Hybrid Optimization Model for Electric Renewable) [5]. This is software will get the system model configurations with a choice of energy sources may be applied in accordance with the availability of the energy potential in the district [6].

The results of modeling system is design configuration hybrid power generation optimum system with output size and capacity of the system, Capital cost, replacement cost, operating and maintenance costs $(\mathrm{O} \&$ $\mathrm{M})$, costs fuel and fuel consumption, and lifecycle cost or Net Present Cost (NPC) is a minimum during the 
project [7]. This result is also expected to meet the electricity need 24 hours and can reduce fuel oil consumption.

\section{METHODS}

\section{A. Research Stages}

The method used in this study includes three main stages:

Stage I: study of electrical load on Moti island; at this stage in doing site survey to determine electricity condition and create load profile of Moti Island 24 hours.

Stage II: study of solar and wind energy potential on Moti island; at this stage in doing wind speed data collection in BMKG office and daily solar radiation data collection on website of NASA surface meteorology and solar energy by using a password coordinate research sites. This data is then analyzed for eligibility of potential energy potential to be applied on the Moti island

Stage III: modelling of Hybrid Power generation system; at this stage in doing determination configuration model of hybrid power generation system, then perform simulations using software HOMER (Hybrid Optimization Model for Electric Renewables), with input data that is daily load data, components data of hybrid power generation, renewable energy and diesel fuel data. Simulations also be done theoretically (manual) for validation value of Net Present Cost (NPC) configuration system is applied.

\section{B. Model Configuration of Hybrid Power Generation on Moti Island.}

There are five (5) models configuration of hybrid system will be analyzed based on availability energy potential to be applied in Moti island, the percentage of system as follows:

1. Diesel (100\%)

2. Photovoltaik; PV (100\%)

3. PV $(70 \%)+$ Diesel $(30 \%)$

4. PV $(50 \%)+\operatorname{Diesel}(50 \%)$

5. PV $(30 \%)+$ Diesel $(70 \%)$

and scheme configuration model can be seen in Figure 24.

C. Capacity and Components cost of Hybrid Power Generation System.

1) Electrical load; Great electrical load can be calculated using equation (1).

$E_{\text {Load }}(W h)=P_{\text {Load }}($ Watt $) \times t_{\text {Load }}($ hour $)$

Where; $E_{\text {Load: load energy; }} \mathrm{P}_{\text {Load: }}$ load power; and $t_{\text {Load: }}$ time usage load.

2) Capacity of diesel generator;

Diesel generators are used to supply peak load on the Diesel $(100 \%)$ configuration system and when SOC is low for battery charging on PV (100\%) and the combined PV + Diesel configuration system. Capacity of diesel generator is determined using equation (2). [8]

$P_{\text {Diesel }}(t)=\frac{E_{\text {Diesel }}(t)}{\eta_{\text {Diesel }}} \times 115 \%$

Where; $P_{\text {Diesel }}$ : diesel generator capacity $(\mathrm{kW})$; $\mathrm{E}_{\text {Diesel }}$ : energy load that must be met generator $(\mathrm{kWh})$; $\eta_{\text {Diesel }}$ : diesel generator efficiency (assuming $=0.9$ ) and the estimated increase capacity by $15 \%$.

3) Capacity of $P V$;

$\mathrm{PV}$ modules used is $\mathrm{P}_{\mathrm{Max}}=300$ Watt $(1956 \times 992 \times 40$ $\mathrm{mm}$ ) [9]; the capacity of PV array and number of PV modules is determined using equation (3) and (4). [10] [11]

$$
\begin{aligned}
& P_{\text {peak }}=\frac{E_{\text {load }} \times I_{0} \times k}{H_{0} \times \eta_{b} \times \eta_{\text {inv }} \times \eta_{m} \times \eta_{b c u}} \\
& N_{P V}=\frac{P_{\text {peak }}}{P_{\text {max } \text { out }}}
\end{aligned}
$$

Where; $\mathrm{P}_{\text {peak: }}$ PV array capacity $(\mathrm{kWp})$; $\mathrm{P}_{\text {max-out: }} \mathrm{PV}$ module nominal capacity $(\mathrm{kWp})$; $\mathrm{E}_{\text {load: }}$ load energy (kWh); $\mathrm{N}_{\mathrm{PV}}$ : number of modules (units). Average daily solar radiation $\left(\mathrm{H}_{0}\right)$ each month $\left(\mathrm{kWh} / \mathrm{m}^{2} / \mathrm{d}\right)$; radiation standard $\left(\mathrm{I}_{0}\right)=1 \mathrm{~kW} / \mathrm{m}^{2}$; Battery efficiency $\left(\eta_{\mathrm{b}}\right)=0.85$; Inverter efficiency $\left(\eta_{\text {inv }}\right)=0.95$; maching efficiency $\left(\eta_{\mathrm{m}}\right)=$ 1 ; BCU efficiency $\left(\eta_{\text {bcu }}\right)=0.95$ and $\mathrm{k}=1.1$ [12].

4) Capacity of wind turbin;

Power and energy output of wind turbine is determined by equation (5) and (6). [13] [14]

$P_{W G}=\frac{1}{2} \rho A_{r} C_{P} V_{W}^{3}=\frac{1}{2} \rho \pi r^{2} C_{P} V_{W}^{3}$

$E_{W G}(t)=P_{W G} \times t$

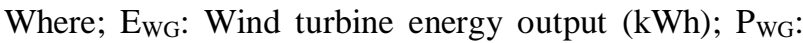
power output of wind turbine at a given wind speed $(\mathrm{kW})$; A and $\mathrm{r}$ : area $\left(\mathrm{m}^{2}\right)$ and radius of rotor/blade turbine $(\mathrm{m})$, and $\mathrm{t}$ : duration time of wind speed; ( 1 day = 24 hours; 1 year $=8760$ hours); Assuming value of $\mathrm{Cp}$ Turbine diameter $2 \mathrm{~m}=0.24$ and value of air density $(\rho)$ $=1.2 \mathrm{~kg} / \mathrm{m}^{3}$.

5) Capacity battery;

Type of battery in this study use Vision 6FM200F, nominal $12 \mathrm{~V} ; 200 \mathrm{Ah}$ or $2.4 \mathrm{kWh} / \mathrm{units}$ [15]. assumptions; Days of outonomy: 4 days; DODmax: 0.75; battery efficiency: 0.85 . Battery capacity and number of battery specified by equation (7) and (8). [16]

Kapasitas battery $(A h)=\frac{E_{\text {Load }} \times \text { Days of outonom }}{D O D_{\max } \times \eta_{\text {bat }} \times V_{\text {bat }- \text { nom }}}$

$N_{\text {bat }}=\frac{\text { Kapasitas battery }(A h)}{\text { Kapasitas battery nominal }(A h)}$

6) Capacity of inverter;

Capacity bidirectional converter (inverter) in every configuration is determined accordance with peak load ( $\left.\mathrm{P}_{\text {peak-load }}\right)$ and consider addition is $15 \%$ of capacity serve. (Efficiency inverter $=0.95$ ). Inverter capacity is determined by the equation (9). [17]

$P_{\text {inv }}=\frac{P_{\text {peak load }} \times 115 \%}{\eta_{\text {inv }}}$

For cost of component system can be seen in table 1 .

\section{HOMER Simulation.}

HOMER determines all system configurations may be applied, then displayed sequentially according to Net Presents Costs (NPC) or also called Life Cycle Costs. HOMER also simulates the operation of the system by providing the calculation of the Energy Balance for every 8,760 hours in a year. If a sensitivity analysis is required, HOMER will repeat the simulation process for 
each variable sensitivity [21]. Relative error of about $3 \%$ [23]. Figure 5 shows is architecture HOMER with three main parts: input, simulation and output.

\section{RESULTS AND DISCUSSIONS}

\section{A. Electricity Condition in Moti Island}

Of the six villages were installed diesel generator, there are two units diesel generator that have been damaged namely in Tafaga village with a capacity of $30 \mathrm{~kW}$ and Guramadehe hamlet in Figur villages with a capacity of $10 \mathrm{~kW}$. While diesel generator is still operating in the Takofi village with a capacity of $30 \mathrm{~kW}$, Figure village of $30 \mathrm{~kW}, 48 \mathrm{~kW}$ of Tafamutu village, Kota Moti village of $150 \mathrm{~kW}, 30 \mathrm{~kW}$ of Tadenas village and nanas hamlet of $5 \mathrm{~kW}$. Hours of operation diesel generator is 4.5 hours/day.

The number of house use electric service as 752 homes and the number of house is not electrified of 35 homes. To use personal generators, there are 5 generator unit that it is connected to the customer's home and for own use many as 215 units of generators with a capacity of 0.9 to $3 \mathrm{~kW}$.

From the survey results also known to consume large are fuel type Solar for diesel generators on Moti island is 100,794 Liters/year, fuel costs amounted IDR 1.007.940.000/year or US\$ 71,995.71/year; and maintenance cost of diesel generator is IDR 58,538,333/year.

\section{B. Load profile}

Load profile estimation of electricity on Moti island to 988 houses, 10 mosques, 8 Musallah/TPA/TPQ, 6 puskesmas or polindes, 6 village office, 16 schools, street lighting in six villages and four carpentry home see in Figure 6. This profile is designed to meet the electrical energy in Moti Island with a 24-hour operation pattern.

From the calculation using equation (1) obtained total daily load energy in Moti Island at $768.99 \approx 770$ $\mathrm{kWh}$ /day and peak load of $105.19 \mathrm{~kW}$.

HOMER simulation results by using a profile in Figure 6 obtained an average daily load energy in a year of 763 $\mathrm{kWh} /$ day, so that total energy of electrical load to be met on Moti island in a year amounted to:

Average load energy per year $=763 \mathrm{kWh} /$ day x 365 days $= \pm 278495 \mathrm{kWh} /$ year.

\section{Wind Energy Potential}

Wind energy potential in Moti Island generally are not large, wind speeds of frequency large in the speed range from $1.5-3.5 \mathrm{~m} / \mathrm{s}$, with duration namely of 32-48 days/year [4]. Figure 7 shows the wind speed frequency that occurred during the year 2011 - 2014 on Moti island.

Wind speed frequency data of Moti island is then used to determine amount of energy production per year in use wind turbines.

Calculation result of average energy output for a capacity wind turbines of 500 Watt and $1 \mathrm{~kW}$ using equation (5) and (6) is; a wind turbine capacity 500 Watt of $399 \mathrm{kWh}$ /year and $1 \mathrm{~kW}$ at $1169 \mathrm{kWh} /$ year, so as to meet the energy load (maximum) Moti Island of 770 $\mathrm{kWh} /$ day or $280,680.6 \mathrm{kWh} /$ year, it takes wind turbines of $500 \mathrm{~kW}$ many as 704 units and $1 \mathrm{~kW}$ as 240 units.

Of the number of wind turbines needed will require a huge investment, with these considerations it can be yearly and monthly Relative error of about $10 \%$ [22] concluded order to meet the needs of electrical load on Moti island are not potential for wind turbines application.

\section{Solar Energy Potential}

Average daily solar radiation in Moti island of 5.96 $\mathrm{kWh} / \mathrm{m}^{2}$ /day, with largest solar radiation of 6.32 $\mathrm{kWh} / \mathrm{m}^{2} /$ day, and the lowest was $5.42 \mathrm{kWh} / \mathrm{m}^{2} /$ day [3].

Figure 8 shows the monthly solar radiation on Moti island by NASA database SMSE (Surface Meteorology and Solar Energy) at Moti island coordinates (DD); $\mathrm{N}: 0.456773$; E:127.410746; with time zone (GMT+07: $00)$.

$E_{e l}=\frac{P_{\text {max }-o u t} \times H_{0} \times \eta_{b} \times \eta_{i n v} \times \eta_{m} \times \eta_{b c u}}{k \times I_{0}}$

Where; $E_{e l}$ : output electrical energy from PV (kWh); $P_{\text {max } \text { out }}$ : nominal capacity module PV $(\mathrm{kWp})$.

By using equation (10), the capacity of $1 \mathrm{kWp} \mathrm{PV}$ generating electrical energy is $6238.13 \mathrm{kWh} /$ year.

To meet energy load needs on Moti island of 770 $\mathrm{kWh} /$ day, then using equation (3) and (4), capacity PV large needed is equal to $204 \mathrm{kWp}$. If using solar modules with a capacity $\mathrm{P}_{\max }=300$ Watt $(1956 \times 992 \times 40 \mathrm{~mm})$ then much required modules as 680 pieces with an array area of $1319.44 \mathrm{~m}^{2}$.

Thus solar energy potential on Moti island terms of compliance burden and vast array area can qualify for photovoltaic application.

\section{E. Comparison Results Hybrid System Configuration}

From simulations using software HOMER obtained fifth comparison output parameter hybrid system configuration can be seen in table 2-3 and Figure 9-14.

In Figure 9 of all configuration system shows of Consumtion AC primary load amounted to 278,494 $\mathrm{kWh} /$ year, and capacity shortage value is 0 (zero) $\mathrm{kWh} /$ year, so that supply electrical energy on the Moti island of $\pm 278,495 \mathrm{kWh} /$ year otherwise met.

The comparison results of energy production and excess electricity configuration system can be seen in Figure 9 and Table 3, comparison results of capital cost and net present cost (NPC) system can be seen in Figure 10 and 11 , comparison results of fuel consumption, fuel cost and cost of electric (COE) can be seen in Figure 1213.

In addition to simulation performed using software HOMER, theoretical calculations (manual) also done calculation results NPC system value as a validation. Comparison theoretical calculation result of value NPC (manual) and value NPC using HOMER software on every configuration system there is a difference of 4.38 $9.27 \%$ with details is; Diesel $(100 \%)$ configuration of $4.42 \%, \mathrm{PV}(100 \%)$ configuration amounted to $5.61 \%$, $\mathrm{PV}(70 \%)+\operatorname{Diesel}(30 \%)$ configuration amounted to $9.27 \%, \mathrm{PV}(50 \%)+\operatorname{Diesel}(50 \%)$ configuration amounted to $4.38 \%$, and the PV $(30 \%)+\operatorname{Diesel}(70 \%)$ configuration amounted to $8.56 \%$. This percentage value can be said to be valid because it is below $10 \%$ monthly relative error values on calculations using HOMER software.

\section{$F$. The Best Configuration System.}

From the comparison result configuration system parameter has been done, the optimal configuration system is determined based on the Net Present Cost 
value (NPC) lowest and can meet needs of load on the Moti island. The optimal configuration system results is $\mathrm{PV}(50 \%)+\operatorname{Diesel}(50 \%)$ configuration as the first option and alternative second option is $\mathrm{PV}(70 \%)+$ Diesel $(30 \%)$ configuration. Analysis of the two models configration following:

1) $P V(50 \%)+\operatorname{Diesel}(50 \%)$ Configuration

The Main Capacity Components System; PV array Capacity of $102 \mathrm{kWp}$ with a number of modules 340 units, the extensive array of 660 m2 (@ 300 Wp/module; $1.956 \times 0.992 \mathrm{~m} 2$ ); Diesel Generator Capacity $120 \mathrm{~kW}$; 213,255.4 Ah battery capacity; 1,067 units of battery $(12 \mathrm{~V} ; 200 \mathrm{Ah})$; and the capacity converter of $130 \mathrm{~kW}$.

Details of Net Present Cost; Figure 15 shows is cash flow of PV $(50 \%)+$ Diesel $(50 \%)$ configuration system for 25 years. If looked at details, the largest expenditure in early is project to US\$ 568,530 , or $37.1 \%$ of total NPC's procurement components system, then the routine expenditure per year is operations cost for all major components system: PV of \$ 102/year, diesel generators at $\$ 2,278 /$ year, Battery of $\$ 106 /$ year, and a converter for $\$ 1,300 /$ year, fuel cost of diesel amounted to $\$$ 42,626/year, maintenance cost and components replacement of PV in the 20th year of $\$ 123,828$; diesel generators in the 11th and 21st for $\$ 12,960$. Battery replacement every 7 years that is in the 7 th, 14th and 21 st year amounted to $\$ 351,469$, and replacement converter in its 15 th year amounted to $\$ 35,802$.

There is a salvage of the components system at the end of the project boundary that is the salvage for PV of $\$$ 92,871 ; diesel generators at $\$ 7,344$; the salvage of $\$$ 100,878 for battery; and for converter of $\$ 11,934$.

Figure 16 result shows of annual electric energy produced output by PV meet needs of the load with effective operation of PV is 4,387 hours/year, and the total electrical energy production $177133 \mathrm{kWh} /$ year. Figure 17 shows energy output of electricity by diesel generators to supply peak load. Diesel generator operating hours in a year is 1,460 hours/year with total electrical energy production of $157,065 \mathrm{kWh} /$ year. COE of $\mathrm{PV}(50 \%)+\operatorname{Diesel}(50 \%)$ configuration of $\$$ $0.493 / \mathrm{kWh}$ or IDR $6,902 / \mathrm{kWh}$. If the user load per house on Moti island is $1.6 \mathrm{kWh} /$ day, then electricity cost per month to be paid IDR 331,296.

\section{2) $P V(70 \%)+$ Diesel (30\%) Configuration}

The Main Capacity Components System; PV array Capacity of $143 \mathrm{kWp}$ with a number of modules 476 units, the extensive array of 924 m2 (@ 300 Wp/module; $1.956 \times 0.992 \mathrm{~m} 2)$; Diesel Generator Capacity $100 \mathrm{~kW}$; 266,535.9 Ah battery capacity; 1,333 units of battery $(12 \mathrm{~V} ; 200 \mathrm{Ah})$; and the capacity converter of $130 \mathrm{~kW}$.

Details of Net Present Cost; Figure 18 shows is cash flow of PV $(70 \%)+$ Diesel $(30 \%)$ configuration system for 25 years. If looked at details, the largest expenditure in early is project to US\$ 713,260 or $45,2 \%$ of total NPC's procurement components system, then the routine expenditure per year is operations cost for all major components system: PV of \$ 143/year, diesel generators at $\$ 1,424 /$ year, Battery of $\$ 133 /$ year, and a converter for $\$ 1,300 /$ year, fuel cost of diesel amounted to $\$$ 28,754/year, maintenance cost and components replacement of PV in the 20th year of \$173,602; diesel generators in the 14 th for $\$ 10,800$. Battery replacement that in the 8th, 15 th and 22nd year amounted to \$ 439,090 and replacement converter in its 15 th year amounted to $\$ 35,802$.

There is a salvage of the components system at the end of the project boundary that is the salvage for $\mathrm{PV}$ of $\$$ 130,202 ; diesel generators at $\$ 1,890$; the salvage of $\$$ 216,208 for battery; and for converter of $\$ 11,934$.

Figure 19 result shows of annual electric energy produced output by PV meet needs of the load with effective operation of PV is 4,387 hours/year, and the total electrical energy production $248,333 \mathrm{kWh} /$ year. Figure 20 shows energy output of electricity by diesel generators to supply peak load. Diesel generator operating hours in a year is 1,095 hours/year with total electrical energy production of $108,732 \mathrm{kWh} /$ year. COE of $\mathrm{PV}(50 \%)+\operatorname{Diesel}(50 \%)$ configuration of $\$$ $0.508 / \mathrm{kWh}$ or IDR $7,112 / \mathrm{kWh}$. If the user load per house on Moti island is $1.6 \mathrm{kWh} /$ day, then electricity cost per month to be paid IDR 341,376.

\section{CONCLUSION}

Based on calculations and data analysis it could be concluded as follows:

1. The need electricity on the Moti island overall unmet because operating time a diesel generator 4.5 hours/day with use of diesel fuel is $100,798 \mathrm{~L} /$ year.

2. The potential for renewable energy on Moti island as a source electrical is the energy of solar radiation with value average daily per year as 5.96 $\mathrm{kWh} / \mathrm{m} 2 /$ day.

3. The first option for configuration model of Hybrid power generation to apply in Moti island is $\mathrm{PV}(50 \%)$ $+\operatorname{Diesel}(50 \%)$ configuration system with a NPC value of US\$ 1,531,546 ( \pm IDR 21.4 Billion; exchange IDR 14,000/\$), which consists a PV capacity of $102 \mathrm{kWp}$, number of PV modules as 340 units and large PV arrays $660 \mathrm{~m} 2,1$ unit diesel generator with a capacity of $120 \mathrm{~kW} ; 1,067$ units of battery $(12 \mathrm{~V} ; 200 \mathrm{Ah})$ and the capacity of converter $130 \mathrm{~kW}$, can meet needs of the electrical load on Moti island amounted to $278495 \mathrm{kWh} /$ year. And the 2nd option of alternative model configurations is $\mathrm{PV}(70 \%)+\operatorname{Diesel}(30 \%)$ configuration system with a NPC value of US\$ 1,577,512 ( \pm IDR 22.1 Billion), which consists a PV capacity of $143 \mathrm{kWp}$ with the number of module is 476 units and a broad array of $924 \mathrm{~m} 2,1$ units diesel generator with a capacity of $100 \mathrm{~kW}, 1,333$ units of battery $(12 \mathrm{~V} ; 200 \mathrm{Ah})$, and the converter capacity of $130 \mathrm{~kW}$.

4. The selling price of electricity for the first and second configuration model is larger than the basic electricity tariff by PT. PLN but the 2nd option model configuration less $42 \%$ of the $\mathrm{kWh}$ price Diesel (100\%) configuration system which is a popular choice in the village and more efficient in use $64.3 \%$ of diesel fuel per year when compared with use of diesel fuel is currently at Moti Island operation pattern generator diesel 4.5 hours/day.

5. Validation results configuration system for NPC value using theoretical calculations (manual) on calculations results using HOMER software there is a difference of 4.38 to $9.27 \%$; is said to be valid because it is under values $10 \%$ monthly relative error (relative error) of HOMER software calculation. 


\section{REFERENCES}

[1] Badan Pusat Statistik (BPS) Kota Ternate, Kota Ternate dalam Angka 2013, Ternate: CV. Rajawali, 2013.

[2] D. P. Sari and R. Nazir, "Optimalisasi Desain Sistem Pembangkit Listrik Tenaga Hybrid Diesel Generator Photovoltaic Array Menggunakan HOMER (Studi Kasus: Desa Sirilogui, Kabupaten Kepulauan Mentawai)," Jurnal Nasional Teknik Elektro, Universitas Andalas, vol. 4, no. 1, pp. 1-12, 2015.

[3] NASA, "NASA Surface Meteorology and Solar Energy, RETScreen Data, Latitude 0.457 / Longitude 127.411," Satellite Data Output, October 2015. [Online]. Available: https://eosweb.larc.nasa.gov/cgi-

$\mathrm{bin} / \mathrm{sse} /$ retscreen.cgi?email=rets\%40nrcan.gc.ca\&step $=1 \&$ lat $=0.4$ 57\&lon=127.411\&submit=Submit. [Accessed October 2015].

[4] Badan Meteorologi Klimatologi dan Geofisika (BMKG), "Data Kecepatan Angin Pulau Moti Tahun 2011 - 2014," BMKG, Maluku, 2015.

[5] Homer Energy, "HOMER Pro 3.1," Microgrid Modeling Software Company, October 2014. [Online]. Available: http://homerenergy.com/HOMER_pro.html. [Accessed January 2015].

[6] R. Rauf, "Konsep Integrasi Pembangkit Berbasis Energi Terbarukan sebagai Sistem Mikrogrid di Kabupaten Pesisir Selatan," Jurnal Nasional Teknik Elektro, Universitas Andalas, vol. 2, no. 2, pp. 79-85, 2013.

[7] A. V. Anayochukwu and E. A. Nnene, "Simulation and Optimization of Hybrid Diesel Power Generation System for GSM Base Station Site in Nigeria," Electronic Journal of Energy \& Environment, vol. 1, no. 1, pp. 37-56, 2013.

[8] A. Purwadi, Y. Haroen, M. Zamroni, N. Heryana and A. Saryanto, "Study of Hybrid PV-Diesel Power Generation System at Sebira Island- Kepulauan Seribu," in IEEE Conference on Power Engineering and Renewable Energy, Bali, 2012.

[9] Panel Surya Jakarta, "Panel Surya 300 WP Shinyoku Polycrystalline," $2015 . \quad$ [Online]. Available: http://panelsuryajakarta.com/panel-surya-300-wp-shinyokupolycrystalline/ . [Accessed November 2015].

[10] M. Chandel, G. D. Agrawal, S. Mathur and A. Mathur, "Techno Economic Analysis of Solar Photovoltaic Power Plant for Garment Zone of Jaipur City," Case Studies in Thermal Engineering, vol. 2, p. 2014, 1-7.

[11] H. A. Guda and U. O. Aliyu, "Design of a Stand-Alone Photovoltaic System for a Residence in Bauchi," International Journal of Engineering and Technology, vol. 5, no. 1, pp. 34-44, 2015.

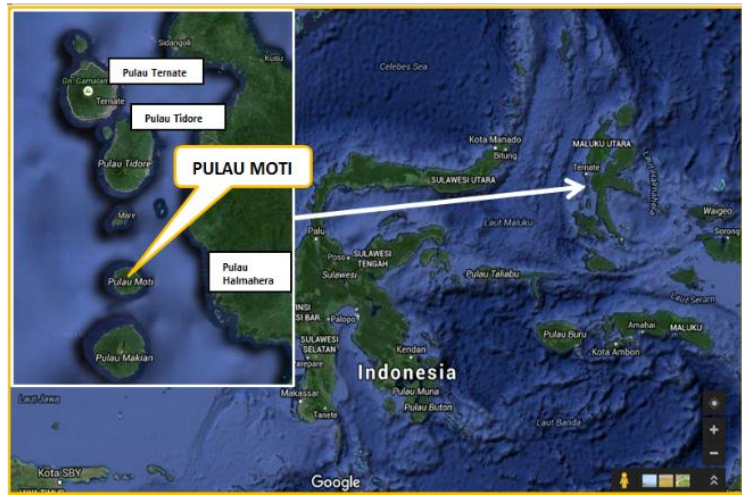

Figure 1. Moti Island Location (Google Maps; www.google.co.id).

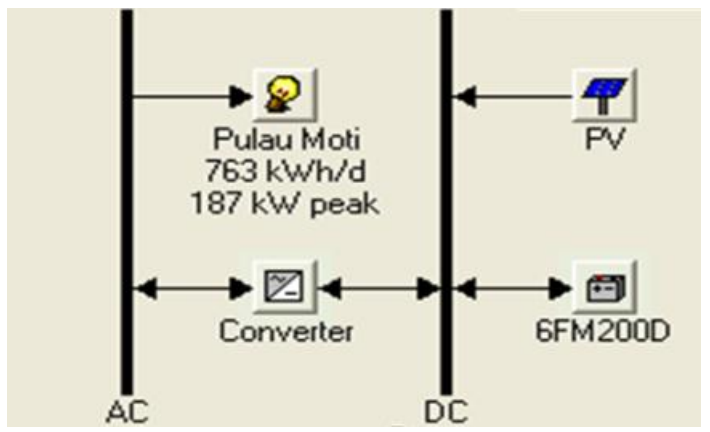

Figure 3. Scheme PV(100\%) configuration model.
[12] Leonics, "How to Choose MPPT Solar Charge Controller for PV Module and Battery," 2015. [Online]. Available: http://www.leonics.com/support/article2_14j/articles2_14j_en.ph p. [Accessed October 2015].

[13] K. Balachander, S. Kuppusamy and P. Vijayakumar, "Comparative Study of Hybrid Photovoltaic-Fuel Cell System / Hybrid Wind-Fuel Cell System for Smart Grid Distributed Generation System," in International Conference on Emerging Trends in Science,Engineering and Technology (INCOSET), Tiruchirappalli, Tamilnadu, India, 2012.

[14] R. Thaib and H. Umar, "Studi Pemanfaatan Pembangkit Listrik Hibrid (Energi Angin-Surya-Diesel) di Kepulauan Simeulue Aceh," in Seminar Nasional Teknik Mesin Universitas Trisakti, Jakarta, 2014.

[15] Osibatteries, "Vision 6FM200D-X Battery 12V 200Ah Sealed Rechargeable Deep," Battery Companies, 2015. [Online]. Available: http://www.osibatteries.com/p-18390-vision-6fm200dx-battery-12v-200ah-sealed-rechargeable-deep-cycle.aspx.

[16] M. Ishaq, U. H. Ibrahim and H. Abubakar, "Design Of An Off Grid Photovoltaic System: A Case Study Of Government Technical College, Wudil, Kano State," Internasional Journal Of Scientific \& Technology Research, vol. 2, no. 12, pp. 175-181, 2013.

[17] D. K. Lal, B. B. Dash and A. K. Akella, "Optimization of PV/Wind/Micro-Hydro/Diesel Hybrid Power System in HOMER for The Study Area," International Journal on Electrical Engineering and Informatics, vol. 3, no. 3, pp. 307-325, 2011.

[18] Kunaifi, "Program Homer Untuk Studi Kelayakan Pembangki Listrik Hibrida di Propinsi Riau," in Seminar Nasional Informatika (semnasIF 2010), Yogyakarta, 2010.

[19] M. Ross, "Verification of the PVToolbox against Monitored Data WatsunPV, HOMER, and SOMES for the Gwaii Haanas PV System," RER Renewable Energy Research: CETC-Varennes, Quebec, 2003

[20] F. Seriff, D. Turcotte and M. Ross, "PV Toolbox: A Comprehensive Set of PV System Components for The MATLAB®/SIMULINK® Environment," in Annual Conference of the Solar Energy Society of Canada Inc (SESCI), Kingston, Ontario, Canada, 2003.

[21] S. Kanata, "Kajian Ekonomis Pembangkit Hybrid Renewable Energi Menuju Desa Mandiri Energi di Kabupaten BoneBolango," Jurnal Rekayasa Elektrika, vol. 11, no. 3, pp. 114-122, 2015.

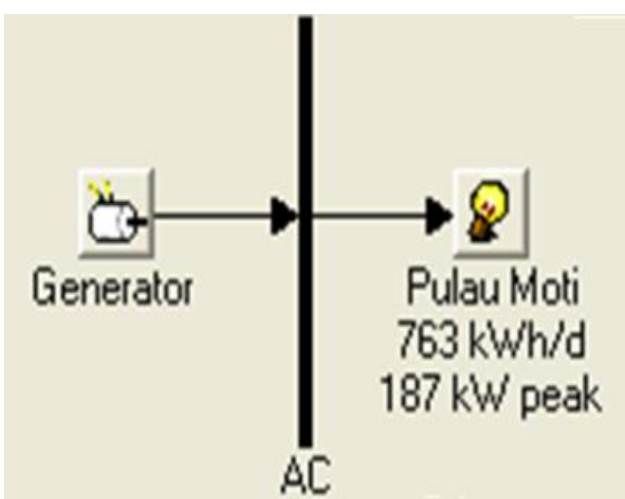

Figure 2. Scheme Diesel (100\%) configuration model.

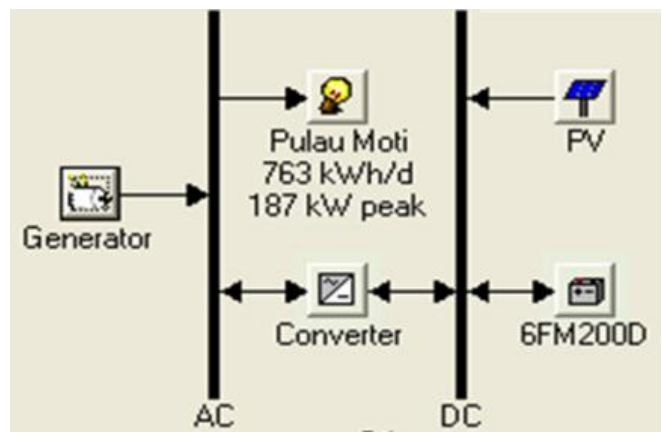

Figure 4. Scheme PV + Diesel configuration model. 


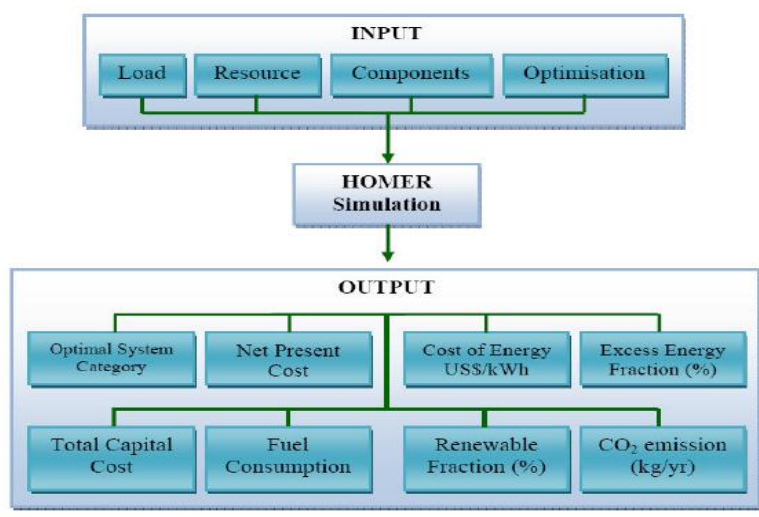

Figure 5. Architecture Simulation and Optimization HOMER [21].

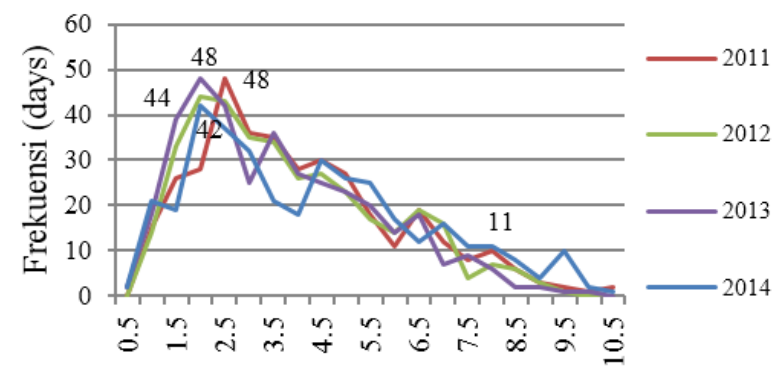

Wind speed $(\mathrm{m} / \mathrm{s})$

Figure 7. Wind Speed Frequency in Moti Island for year 2011-2014 [4].

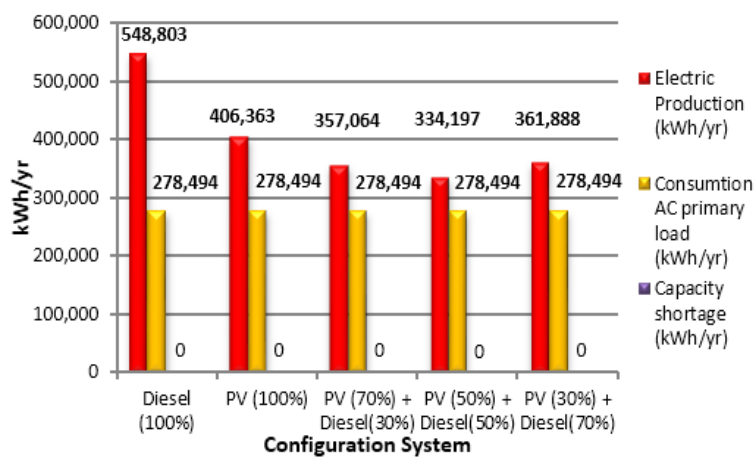

Figure 9. Comparison of Electric Production, Consumption AC primary load, and Capacity shortage.

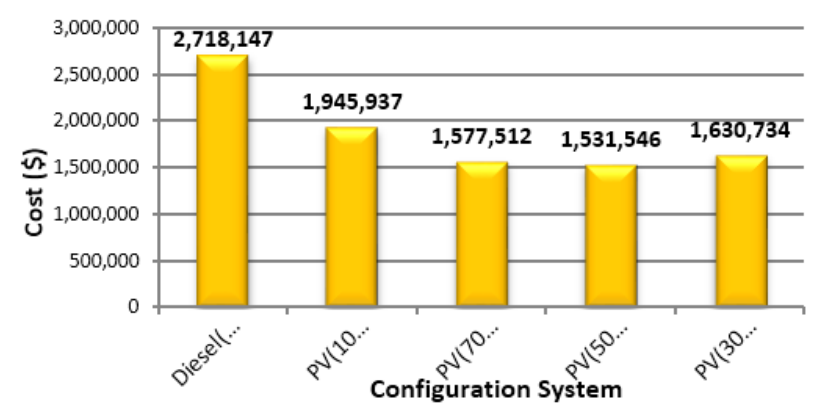

Figure 11. Comparison Net Present Cost Configuration System.

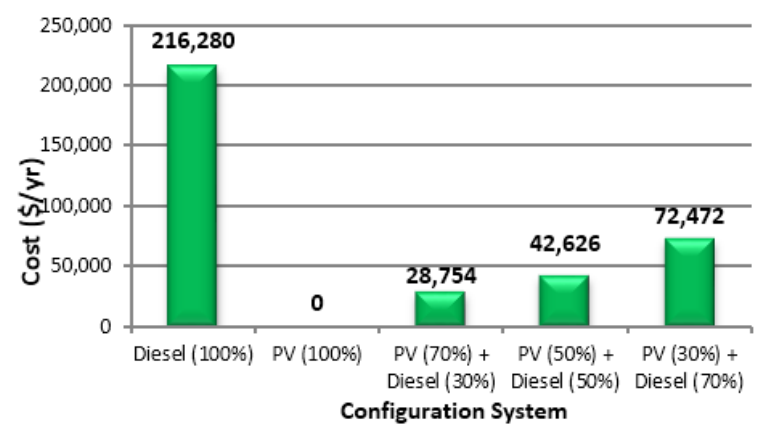

Figure 13. Comparison Fuel Cost.

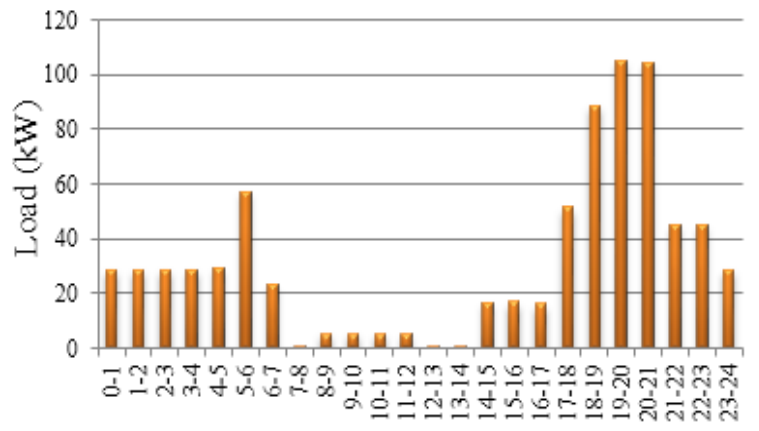

Hour

Figure 6. Load Profile of Moti Island.

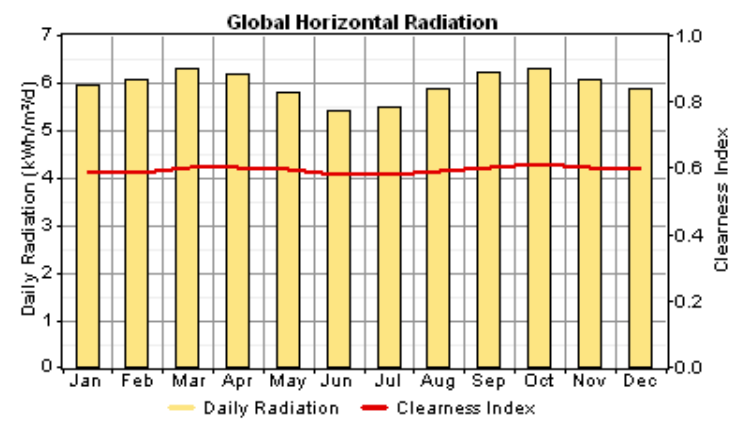

Figure 8. Monthly solar radiation on Moti island [3].

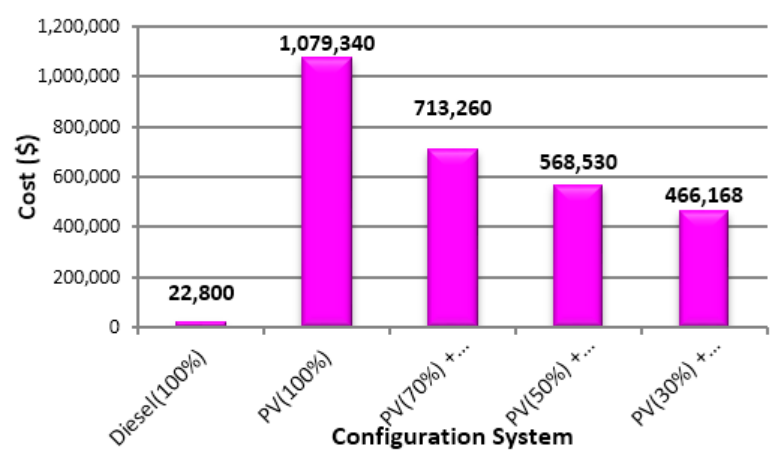

Figure 10. Comparison Capital Cost Configuration System.

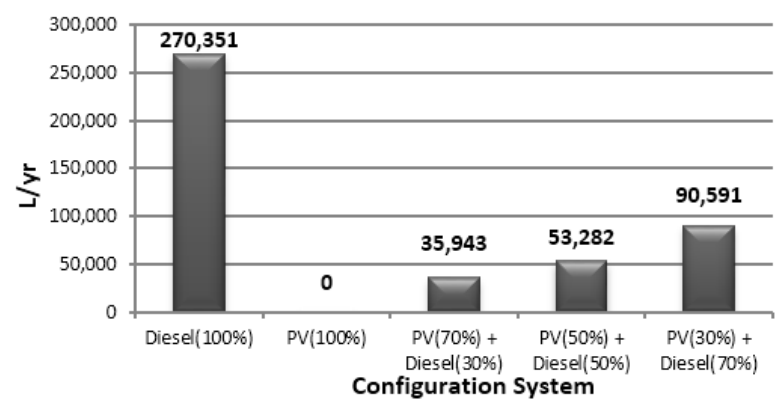

Figure 12. Comparison Fuel Consumption.

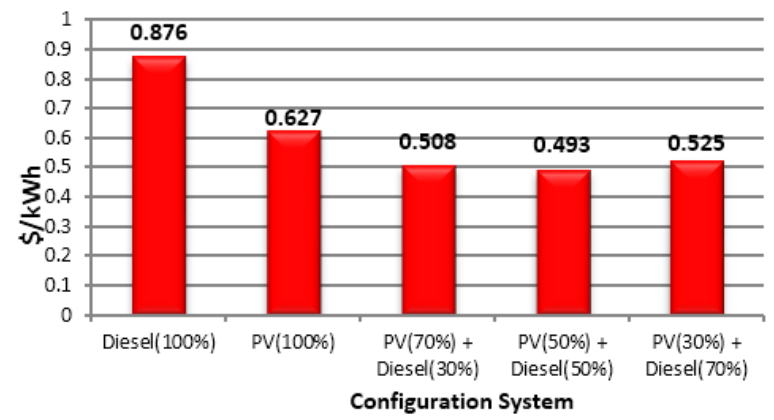

Figure 14. Comparison COE. 


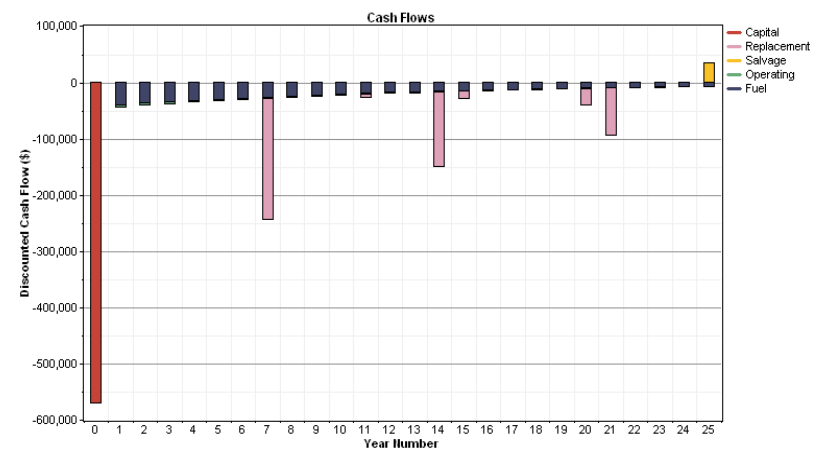

Figure 15. Cash flow of PV(50\%) + Diesel(50\%) configuration system for 25 year.

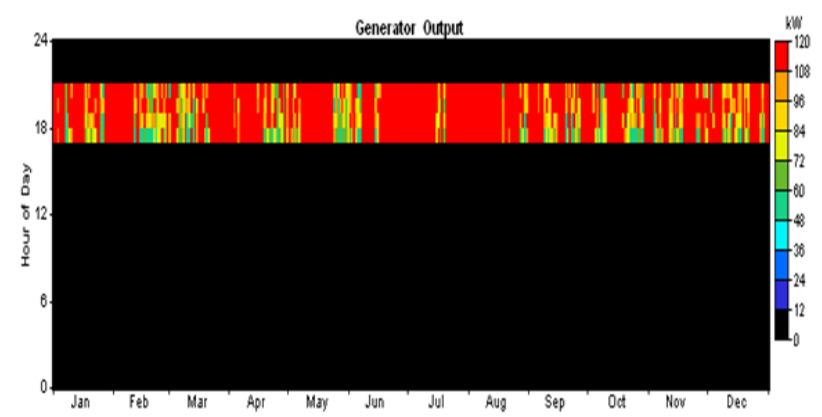

Figure 17. Annual electric produced output by Diesel for PV(50\%)+ Diesel $(50 \%)$ configuration system.

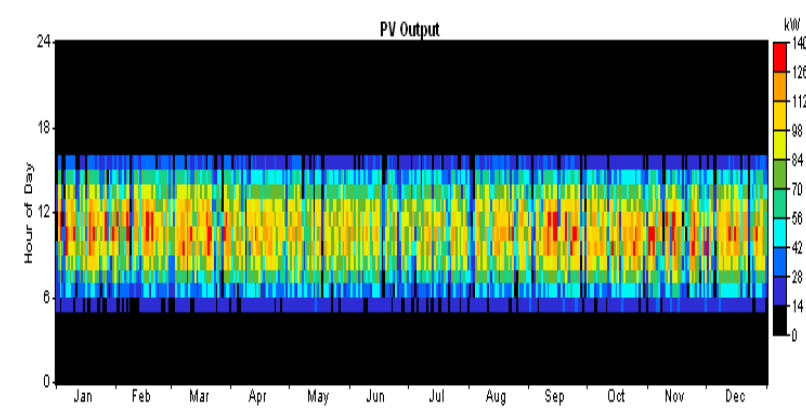

Figure 19. Annual electric produced output by PV for PV(70\%) + Diesel(30\%) configuration system.

TABLE 1.

COST OF COMPONENT SYSTEM

\begin{tabular}{|c|c|c|c|}
\hline Component & Capital Cost & $\begin{array}{l}\text { Replaceme } \\
\text { nt cost }\end{array}$ & $\mathrm{O} \& \mathrm{M}$ \\
\hline $\begin{array}{l}\text { Gen } \\
\text { Diesel }\end{array}$ & US\$ $120 / \mathrm{kW}$ & $\begin{array}{l}90 \% \text { capital } \\
\text { cost }\end{array}$ & $\begin{array}{l}\text { US\$ } 1.3 \\
-1.8 / \mathrm{hr}\end{array}$ \\
\hline $\begin{array}{l}\text { Photovolta } \\
\text { ic }\end{array}$ & $\begin{array}{l}\text { US\$ } 1,214 / \mathrm{kW} \\
{[9]}\end{array}$ & $\begin{array}{l}100 \% \text { capital } \\
\text { cost }\end{array}$ & US\$ $1 / \mathrm{kW}$ \\
\hline Converter & US\$ 306/kW & $\begin{array}{l}90 \% \text { capital } \\
\text { cost }\end{array}$ & $\begin{array}{l}\text { US\$ } \\
10 / \mathrm{kW} / \mathrm{yr}\end{array}$ \\
\hline Battery & $\begin{array}{l}\text { US\$ } 366 / 2.4 \\
\text { kWh [15] }\end{array}$ & $\begin{array}{l}90 \% \text { capital } \\
\text { cost }\end{array}$ & $\begin{array}{l}\text { US\$ } \\
0.1 / \text { unit/yr }\end{array}$ \\
\hline
\end{tabular}

Kurs of Rupiahs; US\$ 1 = IDR 14,000

Fuel price $=$ IDR $10,000 /$ Litre $\approx \$ 0.8 /$ Litre (Survey, 2014)

Interest rate $=7.5 \%$

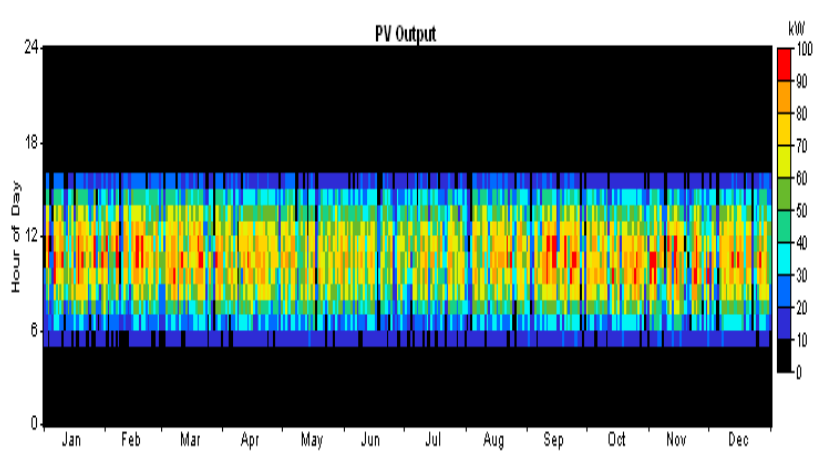

Figure 16. Annual electric produced output by PV for PV(50\%)+ Diesel $(50 \%)$ configuration system.

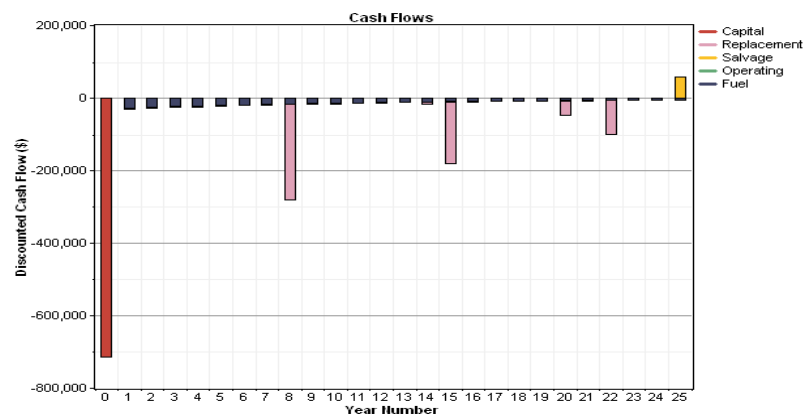

Figure 18. Cash flow of PV(70\%) + Diesel(30\%) configuration system for 25 year.

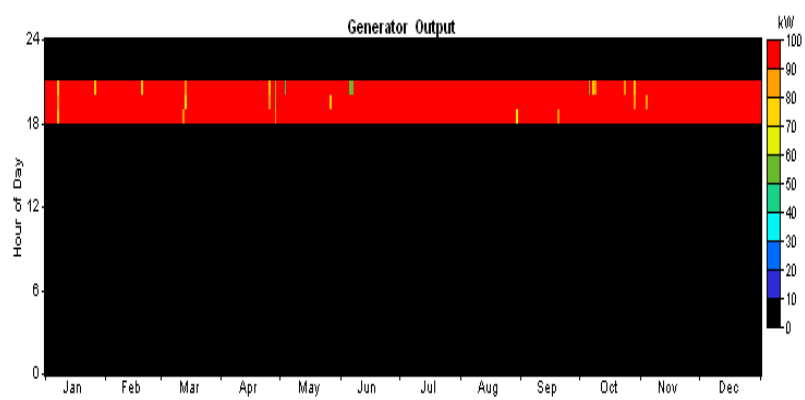

Figure 20. Annual electric produced output by Diesel for PV(70\%) + $\operatorname{Diesel}(30 \%)$ configuration system.

TABLE 2.

OPTIMAL CAPACITY OF COMPONEN SYSTEM

\begin{tabular}{|c|c|c|c|c|}
\hline \multirow{2}{*}{$\begin{array}{l}\text { percentage } \\
\text { configuration }\end{array}$} & \multicolumn{4}{|c|}{ Optimal capacity of Componen System } \\
\hline & $\begin{array}{l}\text { PV } \\
(\mathrm{kWp})\end{array}$ & $\begin{array}{l}\text { Diesel } \\
(\mathrm{kW})\end{array}$ & $\begin{array}{l}\text { Battery } \\
\text { (unit) }\end{array}$ & $\begin{array}{l}\text { Converter } \\
(\mathrm{kW})\end{array}$ \\
\hline $\operatorname{Diesel}(100 \%)$ & 0 & 190 & 0 & 0 \\
\hline PV $(100 \%)$ & 234 & 0 & 2014 & 190 \\
\hline $\operatorname{PV}(70 \%)+\operatorname{Diesel}(30 \%)$ & 143 & 100 & 1333 & 130 \\
\hline $\operatorname{PV}(50 \%)+\operatorname{Diesel}(50 \%)$ & 102 & 120 & 1067 & 130 \\
\hline $\operatorname{PV}(30 \%)+\operatorname{Diesel}(70 \%)$ & 62 & 120 & 920 & 130 \\
\hline
\end{tabular}

TABLE 3.

EXCESS ELECTRICITY CONFIGURATION SYSTEM

\begin{tabular}{lll}
\multicolumn{2}{c}{ EXCESS ELECTRICITY CONFIGURATION SYSTEM } \\
\hline \hline Configuration & $\begin{array}{l}\text { Excess electricity } \\
(\mathrm{kWh} / \mathrm{yr})\end{array}$ & $\%$ \\
\hline Diesel $(100 \%)$ & 270,308 & 49.3 \\
PV $(100 \%)$ & 52,141 & 12.8 \\
PV $(70 \%)+$ Diesel $(30 \%)$ & 29,824 & 8.35 \\
PV $(50 \%)+$ Diesel $(50 \%)$ & 10,672 & 3.19 \\
PV (30\%) + Diesel (70\%) & 43,658 & 12.1 \\
\hline \hline
\end{tabular}

